4. Moore Alex (2004), Ballroom Dance, AST Press; Astrel, Moscow, 191 p. (rus).

5. Osadtsiv T. P. (2010), History of dance, in: Suchasni problemy rozvytku teorii ta metodyky himnastyky. Coll. Science. materials, Vol. 11, Lviv, p. 48-51 (ukr).

6. Osadtsiv T.P. (2001), Sports Dance, ZUKTS Press, Lviv, 340 p. (ukr).

7. Striganova V. M., Uralskaya V. I. (1978), Modern ballroom dance, Education Press, Moscow, 430 p. (rus).

8. The Ballroom Technique of Latin American Dancing (2003), The Imperial of Society of Teachers of Dancing, London, p. 27-52 (eng).

9. Moor A. (1968), Kingston - on Thames. International Council of Ballroom Dancing and Official Board of Ballroom Dancing, The World Dance Programme, London (eng).

10. Clarkson P. M., Skrinar M. (1988), The science of dance, in: The science of dance training; dance, dancers remain subject to the same unyielding, Human Kinetics Books, Champaign, p. 17-21 (eng).

(C) Осадиів Тарас

Надійшла до редакції 16.03.2016

УДК 94(477.7):32

\title{
СЛИВЕНКО ВЯЧЕСЛАВ,
}

кандидат історичних наук, доцент кафедри менеджменту та туристичного бізнесу

Дніпропетровського національного університету імені Олеся Гончара

\section{КАДРОВА ПОЛІТИКА ПРОКУРАТУРИ ТА ВЗАЕМОВІДНОСИНИ З МІСЦЕВОЮ ВЛАДОЮ В УСРР y 1920-mi pp.}

\begin{abstract}
Статтю присвячено аналізу маловивченого аспекту здійснення підбору та підготовки кадрів для органів прокуратури в 1920-ті рр. На основі широкого кола джерел автором висвітлені кадрові проблеми відомства та показані основні заходи влади з виправлення ситуації й підвищення рівня професіоналізму співробітників. Розкрито причини конфліктів між прокуратурою й місцевою владою та відмічено вплив партії на кадрову політику відомства.
\end{abstract}

Ключові слова: прокуратура; кадрова політика; професіоналізм; юстиція; правосуддя; неп.

Постановка проблеми і стан її вивчення. У системі правоохоронних органів прокуратура $є$ найважливішою інституцією, оскільки саме вона виконує функцію нагляду за дотриманням законності. За часів незалежності нашої держави прокуратуру намагалися реформувати неодноразово, але ці зміни ніяк не впливали на докорінне переродження органу. І сьогодні, на думку багатьох політиків та науковців, саме непродумана кадрова політика в прокуратурі є причиною того, що в країні стрімко зростає хвиля злочинності та залишаються нерозслідуваними багато резонансних злочинів [1]. Міжнародні експерти також указують на те, що причиною погіршення криміногенної ситуації в країні $\epsilon$ те, що на кадрові рішення впливає політика, а реформа відомства фрактично спрямована тільки на скорочення штату прокуратур [2].

Останнім часом спостерігається зростання інтересу дослідників до історії прокуратури. Цій проблемі присвячено чимало робіт, проте у своїй більшості вони не мають наукового характеру і являють собою короткі екскурси в історію регіональних прокуратур, часто написані не фаховими істориками, а працівниками правоохоронних органів. З'являються також і наукові дослідження, присвячені історії прокуратури, проте їхня кількість незначна. Так, окремі аспекти функціонуван- ня прокуратури УСРР у 1920-х рр. розглядають у своїх роботах Л. І. Грицаєнко, О. В. Кошман, О. І. Вікторов, В. В. Мурза, І. Б. Усемко, Г. М. Шестопалов та ін. [3-7].

Мета статті - аналіз еволюції кадрової політики прокуратури УСРР та оцінка партійно-державного впливу на її діяльність у досліджуваний період. Вибір теми зумовлений тим, що для успішного реформування відомства істотну допомогу може надати історичний досвід, який дозволить відтворити реальну картину тогочасних подій та не повторити помилок минулого.

Виклад основного матеріалу. Після організації прокуратури в республіці в червні 1922 р. і практично протягом усього періоду непу кількість професійних кадрів була недостатньою для вирішення поставлених перед відомством завдань. Найбільш гостро це відчувалося в першій половині 1920-х рр. Навіть збільшення персоналу більш ніж удвічі в 1925 р., що стало наслідком державного курсу на зміцнення законності, не вирішило остаточно проблеми $[5$, с. 275]. Проте саме цей захід багато в чому пояснює активізацію прокурорської діяльності в другій половині 1920-х рр. Для укомплектування штату прокуратури Народний комісаріат юстиції УСРР (далі - НКЮ) оголосив мобілізацію всіх членів КП(б)У, які працювали в правоохоронній сфері республіки, вихідців із "соціально близьких" трудових класів: робітників і селян. Проте 
подібна спрямованість кадрової політики радянської держави відразу наштовхнулася на проблему підбору серед "своїх людей" таких, що за професійними якостями відповідали всім вимогам до кандидатів на посаду прокурора. Тому в більшості губерній відразу склалася ситуація, коли протягом досить тривалого часу значна частина посад у прокуратурах залишалася вакантною. Так, у Катеринославі в січні 1923 р. із восьми помічників губернського прокурора було призначено тільки п'ять, у Харківській та Одеській губерніях в окружних прокуратурах не було заповнено близько чверті посад [15, арк. 137]. Це призвело до того, що прокуратура далеко не відразу впоралася з усіма покладеними на неї завданнями. Наприклад, коли в лютому 1923 р. усі губернські прокуратури були перевірені інспекцією НКЮ, було виявлено багато недоліків, у тому числі за основними напрямками діяльності [6, с. 28].

Слід зауважити, що проблеми в роботі прокуратури були зумовлені цілком об'єктивними обставинами, найсерйознішою з яких була катастрофрічна нестача кваліфрікованих юристів. Таке становище склалося внаслідок того, що кадрові вимоги до працівників радянського правосуддя були більш "жорсткими", ніж у інших сферах, де залучення "старорежимних" фахівців із "сумнівним" соціальним походженням у 20-ті рр. минулого століття перетворилося на звичайну практику. Охороняти "соціалістичну законність" могли тільки ті, хто справою довів відданість ідеалам революції. Так, згідно з положенням "Про прокурорський нагляд" 1922 р., працівниками відомства не могли бути особи, що перебували в антирадянських партіях або навіть помічені в період громадянської війни "в нелояльності" до радянської влади. Урешті-решт на посади в прокуратуру призначалися працівники, які не мали не тільки спеціальної юридичної, а іноді навіть і середньої освіти [7, с. 148]. Так, статистичні дані "першого набору" прокурорських працівників УСРР свідчать про те, що абсолютна більшість (близько 87 \%) були членами КП(б)У [3, с. 96]. За соціальним складом серед співробітників прокуратури робочі становили - $30 \%$, селяни - $9 \%$, інтелігенція

- $61 \%$ Освітній рівень співробітників був таким: із домашньою освітою - 8 \% (відповідало гімназичному рівню), з нижчою - $46 \%$, із середньою - $19 \%$, з вищою $7 \%$, з вищою юридичною освітою - $11 \%$, закінчили спеціальні курси - 9 \% [4, с. 115]. Не менш важливим показником був стаж роботи в органах радянської юстиції, який поділяв співробітників на такі категорії: 5 років $16 \%$, від 3 до 5 років - $23 \%$, від 1 до 3 років - $46 \%$ і менше року - $15 \%[8$, с. 137$]$.

3 наведених нижче статистичних даних випливає, що працівники першого складу прокуратури УСРР були в основному комуністами з інтелігенції. Такий стан суперечив соціальній політиці влади, і більшовики були змушені вести цілеспрямовану роботу щодо поступової заміни представників інтелігенції робітниками й селянами, тобто виховувати "нову інтелігенцію", радянську, усім зобов'язану партії, а значить і повністю віддану їй. За освітою і досвідом роботи в органах юстиції співробітники не відповідали рівню вимог до прокурорської діяльності, і це негативно відбивалося на ефективності їх роботи. Тому керівництву НКЮ УСРР довелося приділяти велику увагу підвищенню рівня професійної підготовки й зниженню "плинності" кадрів в органах прокуратури.

Важливо відзначити, що про недостатній професіоналізм також свідчить і аналіз персональних даних перших губернських прокурорів республіки. Так, Миколаївський губернський прокурор (далі - губпрокурор) К. Вансович мав незакінчену середню освіту [13, арк. 53]. Першим Одеським губпрокурором був призначений
I. Завадський, який устиг закінчити тільки другий курс юридичного фракультету Московського народного університету імені А. Шанявського. У 1923 р. його змінив партійний функціонер В. Чернявський, який мав тільки початкову освіту [14, арк. 82]. Першим Катеринославським губпропрокурором призначили 22- річного Й. Славина, який устиг тільки вступити на юридичний факультет Київського університету (не закінчив). Його в 1923 р. змінив Р. Карасик, який мав середню освіту та до призначення очолював фрінансовий відділ губернії [12, арк. 49]. Чи варто дивуватися, якщо навіть у столиці УСРР - Харкові - губпрокурором був призначений зубний технік (за іншими даними - учитель) Г. Желєзногорський [15, арк. 184].

Для виправлення ситуації і якісного поліпшення кадрового складу прокуратур керівництвом НКЮ в 1923 р. була розроблена "Інструкція з організації губернських атестаційних комісій". Допомогти роботі комісій повинна була й нова, більш детальна фрорма з обліку кадрів. Наприкінці 1923 р., проаналізувавши висновки атестаційних комісій, керівництво прокуратури УСРР прийшло до невтішних висновків про необхідність кардинальної зміни політики комплектування органів у напрямку підвищення професіоналізму [9, с. 19].

Необхідно відзначити, що питання створення системи спеціальної освіти розглядалися вже з перших днів утворення прокуратури. Так, на нараді завідувачів губернських відділів юстиції в липні 1922 р. у Харкові було вирішено відкрити короткострокові юридичні курси й відповідні фракультети інститутів народного господарства [7, с. 145]. У вишах передбачалося встановити трирічний термін навчання, причому в Харкові планувалося організувати освоєння загальноосвітніх дисциплін і базову юридичну підготовку за трьома напрямками - судовим, адміністративним і господарським. Крім того, керівництво НКЮ вважало, що в умовах непу майбутнім прокурорам промислових регіонів для підвищення ефективності роботи необхідно поглиблене вивчення економіки. Так, для співробітників південних губерній республіки вивчення питань товарообміну було організовано в Одесі [9, с. 21].

Розв'язуючи проблему, уже в 1924 р. НКЮ розпочав створення системи вищої юридичної освіти в республіці. Були створені юридичні фракультети в інститутах народного господарства в Києві, Харкові та Одесі. При цьому короткострокові курси роботи не припиняли, і тільки за перші п'ять років роботи навчання на них пройшли близько 170 співробітників прокуратури. Слід зазначи ти, що до початку 1929 р. приблизно $20 \%$ помічників окружних прокурорів закінчили курси, 13 \% закінчили юридичні фракультети і ще 2 \% мали неповну юридичну освіту [15, арк. 275]. Отже, якісний склад працівників прокуратури до кінця 1920-х рр. був усе ще незадовільним. Розуміючи всю важливість кадрової політики в органах прокуратури й намагаючись вирішити проблему, у листопаді 1929 р. на пленумі ЦК КП(б)У була прийнята спеціальна резолюція "Про кадри", у якій питання вищої юридичної освіти в УРСР визначалося як першочергове [9, с. 23].

Вирішуючи питання підвищення професійного рівня співробітників органів прокуратури наприкінці 1920-х рр., партійне керівництво УСРР відзначало, що поряд 3 обов'язковою партійністю прокурорських працівників, у розряд першочергових наполегливо висувалася вимога збільшення кількості представників робітничого класу й найбіднішого селянства. У другій половині 1920-х рр. відбулися якісні зміни соціального складу відповідальних працівників прокуратури низової ланки. Тепер серед співробітників апарату робітники становили - $67 \%$, селяни - $17 \%$, що, у свою чергу, призвело 
до ще більшого зниження рівня освіченості співробітників прокуратури навіть у порівнянні з періодом 1922 1925 рр. [15, арк. 282]. Намагаючись виправити ситуацію, у Катеринославі, Одесі та Миколаєві при губернських відділах юстиції створювали юридичні товариства, членами яких були судді, прокурори, адвокати та інші працівники юридичних установ. На зборах товариств зазвичай розглядалися актуальні правові питання, робилися доповіді та запити, що, безсумнівно, сприяло підвищенню кваліфрікації юристів [9, с. 27].

Слід визнати, що конфлікти між прокуратурою місцевою владою були характерні для багатьох регіонів СРСР. Однак в УСРР через особливості переходу республіки до непу, вони відбувалися в найбільш загостреній формі. Така ситуація склалася через те, що місцеві керівники часто продовжували підмінювати законність "революційною правосвідомістю", що в умовах запровадження непу ставало неприпустимим. У зіткненнях із владою прокурори не завжди перемагали місцеве свавілля. Зокрема такі суперечки призвели до відсторонення від посад перших губернських прокурорів Катеринослава (Й. Славина) та Миколаєва (К. Вансовича) [15, арк. 92]. Непоодинокі були випадки, коли НКЮ відряджав спеціальні комісії для розслідування конфліктів у відносинах між прокуратурою і місцевою владою. Проте, коли в другий половині 1920-х рр. у республіці намітилися позитивні тенденції в боротьбі за законність, характер відносин між прокуратурою і місцевою владою змінився з протистояння на взаємодію. 31926 р. керівників прокуратур включали до складу місцевих партійних комітетів і вони почали брати активну участь у засіданнях партійно-державних органів що дозволило уникати конфліктів та мирно розв'язувати найбільш важливі питання [10; 11].

\section{Висновки}

Отже, на початку 1920-х рр. після організації прокуратури в республіці проблеми в її роботі були зумовлені катастрофічною нестачею кваліфрікованих юристів. Для укомплектування прокуратури владою було проведено мобілізацію всіх правоохоронців - членів КП(б)У, здебільшого робітничо-селянського походження. Проте за своїми професійними якостями такі працівники не відповідали вимогам прокурорської діяльності, тому в республіці протягом досить тривалого часу значна частина посад у прокуратурах залишалася вакантною. Таке становище склалося внаслідок того, що кадрові вимоги до працівників радянської юстиції були більш "жорсткими", ніж в інших сорерах, де допускалося залучення фахівців із дореволюційним стажем роботи. Для вирішення проблеми в губернських центрах були організовані короткострокові юридичні курси та відповідні факультети в інститутах народного господарства. У другій половині 1920-х рр. кадрова політика влади на подальше збільшення в прокуратурі кількості відданих партії робітників та селян призвела до значного зниження ефективності роботи відомства внаслідок значного па- діння рівня компетентності співробітників. Наспіх створена система юридичної освіти не змогла повною мірою задовольнити потребу у фахівцях. Щоб хоч якось вирішити проблему, на місцях організовувалися такі форми підвищення кваліфрікації співробітників, як юридичні товариства. Незважаючи на низький рівень професіоналізму працівників, наприкінці 1920-х рр. прокуратура в основному виконувала завдання партійної верхівки, яка фрактично мала монополію на владу. Але в зіткненнях із владою прокурори не завжди перемагали свавілля місцевих керівників і лише залучення їх до роботи партійно-державних органів дозволило уникати конфліктів. Домінуючий вплив партії на кадрову політику супроводжував прокуратуру протягом усього радянського періоду.

\section{ЛПЕРАТУРА}

1. Кадровая политика прокуратуры [Електронний ресурс]. - Режим доступу : http://obozrevatel.com/politics.

2. Реформирование прокуратуры [Електронний ресурс]. Режим доступу : http://www.gp.gov.ua/ua/reforms.

3. Грицаєнко Л. І. Історико-правові витоки інституту прокуратури в Україні / Л. І. Грицаєнко // Вісник прокуратури. 2008. - № 2. - С. 94-105.

4. Кошман О. В. Історія створення і діяльності прокуратури в XIX-XX століттяX / О. В. Кошман // Вісник прокуратури. 2011. - № 9. - C. 114-117.

5. Мурза В. В. Прокуратура УССР и высшие органы государственной власти (20-е - начало 30-х гг.) / В. В. Мурза // Вісник Харківського національного університету внутрішніх справ. - 2001. - Вип. 16. - С. 273-279.

6. Усемко И. Б. Украина в годы нэпа: судьба курса на ревзаконность / И. Б. Усемко - Харьков : Арго, 1995. - 53 с.

7. Шестопалов Л. Н. Исторические предпосылки становления и развития органов прокуратуры Украины // Вестник Днепропетровского государственного университета внутренних дел. - 2012. - Вып. № 2. - С. 143-152.

8. Сливенко В. А. Еволюція більшовицьких поглядів на злочинність та правоохоронну діяльність в 1920-х рр. / В. А. Сливенко // Проблеми політичної історії України. - 2015. - Вип. 10. - С. $131-137$.

9. Сливенко В. А. Формирование новой системы профессиональной подготовки сотрудников правоохранительных органов УССР в 1920-е гг. / В. А. Сливенко // Ученые записки Витебского государственного университета им. П. М. Машерова. - 2015. - Т. 19 (285). - С. 17-30.

10. Справочник по истории КПСС [Електронний ресурс]. Режим доступу : http://www.knowbysight.info.

11. Історія прокуратури України [Електронний ресурс] Режим доступу : http://www.gp.gov.ua/ua/dark_ages.html.

12. Державний архів Дніпропетровської області, ф. 1518 , оп. 1, спр. 4, 126 арк.

13. Державний архів Миколаївської області, ф. 122, оп. 1 , спр. 1, 170 арк.

14. Державний архів Одеської області, ф. 1190, оп. 1, спр. 5, 136 арк.

15. Центральний державний архів громадських об'єднань України, фр. 1, оп. 2, спр. 2100, 371 арк.

\section{Сливенко Вячеслав,}

кандидат исторических наук, доцент кафедры менеджмента и туристического бизнеса Днепропетровского национального университета имени Олеся Гончара

\section{КАДРОВАЯ ПОЛИТИКА ПРОКУРАТУРЫ И ВЗАИМООТНОШЕНИЯ СМЕСТНОЙ ВЛАСТЬЮ В УССР В 1920-e г2.}

Статья посвящена анализу малоизученного аспекта осуществления подбора и подготовки кадров для органов прокуратуры УССР в 1920-е гг. На основе широкого круга источников автором показаны основные 
проблемы ведомства, вызванные катастрофической нехваткой квалифицированных юристов. Особое внимание автором уделено анализу политики власти на постоянное увеличение в прокуратуре количества преданных партии рабочих и крестьян, что и привело к кадровому кризису в ведомстве. Отмечено, что одной из главных причин сложившегося положения стали более "жесткие", чем в других сферах, требования к работникам советской юстиции, где допускалось привлечение специалистов с дореволюционным стажем работы. Показано, что вновь созданная система юридического образования не смогла в полной мере удовлетворить потребность в специалистах. Установлено, что одним из способов решения проблемы стала организация таких форм повышения квалификации сотрудников как юридические общества. В конфликтах с местной властью прокуроры не всегда побеждали беззаконие и только привлечение к их работе партийно-государственных органов позволило избегать конфликтов. Отмечено, что доминирующее влияние партии на кадровую политику сопровождало прокуратуру в течение всего советского периода.

Ключевые слова: прокуратура; кадровая политика; профессионализм; юстиция; правосудие; нэп.

Slivenko Vyacheslav, Candidate of Historical Sciences, assistant professor of management and tourism business department of the Dnipropetrovsk National University Oles Honchar

\section{FEATURES OF THE PROSECUTOR'S OFFICE OF PERSONNEL POLICY SOVIET UKRAINE IN THE 1920s}

This article analyzes the unstudied aspects of the formation of the personnel policy of the Soviet Ukraine's prosecutor's office in the 1920s. The theme is caused by necessity of reforming the modern law enforcement. Research tasks were solved by using scientific methods, analysis, synthesis, synthesis and comparison.

The author has made an analysis of personnel policy of the Soviet government in the 1920s. The purpose of this policy was a constant increase in the number of prosecutors from among the workers and peasants. This led to a significant reduction in the level of professionalism of staff. To enhance the professionalism of prosecutors government organized short-term courses and University School of Law. But they were not able to fully meet the demand for specialists. In order to improve the efficiency of the prosecutor's office in the regions of the Soviet Ukrainian government workers have established forms of staff development as a legal society. In conflict with the government prosecutors are not always won local lawlessness. Attraction prosecutors to work in government agencies has allowed to avoid conflicts. By the end of the 1920 s staffing problems were solved and the prosecutor's office, began to deal with the tasks of the party elite, who actually had a monopoly on power. The dominant influence of government on the implementation of personnel policy accompanied by a prosecutor during the Soviet period. In future research the author will be related to the analysis of problems of law enforcement agencies of the state in terms of crisis and democratic reforms.

Keywords: the prosecutor's office; personnel policy; professionalism; justice; court.

\section{REFERENCES}

1. Personnel policy Public Prosecutor, available at: http://obozrevatel.com/politics (rus).

2. Reform of the Prosecutor's Office, available at: http://www.gp.gov.ua/ua/reforms (rus). (ukr).

3. Grytsayenko L. I. (2008), Historical of the prosecution in Ukraine, in: Visnyk prokuratury [Prosecution Bulletin], № 2, pp. 94-105

4. Koshman O. V. (2011), History of the prosecution in the XIX-XX centuries, in: Visnyk prokuratury [Prosecution Bulletin], № 9 , pp. 114-117 (ukr).

5. Murza V. (2001), The prosecutor's office of the Ukrainian SSR and the higher institutes of state power (1920-1930 years), in: Visnyk Kharkivskoho natsionalnoho universytetu vnutrishnikh sprav, № 16, pp. 273-279 (rus).

6. Usemko I. (1995), Ukraine in the years of the NEP: the fate of the course on the legality, Kharkiv, 53 p. (rus).

7. Shestopalov L. (2012), Historical background of formation and development of the Prosecutor's Office of Ukraine, in: Vestnik Dnepropetrovskogo gosudarstvennogo universiteta vnutrennikh del, № 2, pp. 143-152 (rus).

8. Slivenko V. A. (2015), Evolution Bolshevik views on crime and law enforcement in 1920, in: Problemy politychnoi istorii Ukrainy, № 10, pp. 131-137 (ukr).

9. Slivenko V. A. (2015), Formation of a new system of professional training law enforcement system of staff of the Ukrainian SSR in 1920, in: Uchenye zapiski Vitebskogo gosudarstvennogo universiteta im. P. M. Masherova, №19 (285), pp. 17-30 (rus).

10. Directory of CPSU history, available at: http://www.knowbysight.info (rus).

11. History Prosecutor of Ukraine, available at: http://www.gp.gov.ua/ua/dark_ages.html (ukr).

12. State Archives of Dnipropetrovsk region, fond 1518, opys 1, sprava 4, 126 p. (ukr).

13. State Archives of Mykolayiv region, fond 122, opys 1, sprava 1, 170 p. (ukr).

14. State Archives of Odessa region, fond 1190, opys 1, sprava 5, $136 \mathrm{p}$. (ukr).

15. Central State Archive of Public Organizations of Ukraine, fond 1, opys 2, sprava 2100, 371 p. (ukr).

(C) Сливенко Вячеслав

Надійшла до редакції 26.04.2016 